\title{
Development of Electronic Students' Worksheet Linear Function-Problem Based Using Desmos Application
}

\author{
Dyah Ayu Karindra ${ }^{1}$, Rooselyna Ekawati ${ }^{2}$ \\ ${ }^{1,2}$ Program Studi Pendidikan Matematika, Fakultas Matematika dan Ilmu Pengetahuan Alam, Universitas Negeri Surabaya, \\ J1. Ketintang, Gayungan, Surabaya, Jawa Timur, 60231 \\ dyahayukarindra@gmail.com
}

\begin{abstract}
One effort to facilitate students in online learning and face-to-face learning during Covid-19 pandemic is the use of digital student worksheets, as an effort to practice students' cognitive in mathematics. These research goals are to develop digital students' worksheet of linear function-problem based using Desmos to decrease learning loss effect in students' motivation and comprehension. And, also to know, the eligibility analysis result of worksheet that has already been made. Desmos is a web-based application, which specially created to be used in mathematics learning. It combines features of graphic calculator and classroom activities to help students study and love math. Research model in this study used ADDIE with a small group experiment using six students of SMPN 3 Surabaya as subjects. Eligibility analysis from the worksheet gains a validity score of 3.71, with very valid criteria. Practical score 3.74, with very practical criteria. And effective, since all six subjects in Study Result Test, gain higher score than the minimum score criteria of SMPN 3 Surabaya. It may take note that, it needs bigger experiments with more subjects to evaluate effective aspect further and comprehensively. This worksheet can be an alternative media for secondary students to practice linear function.
\end{abstract}

Keywords: E-LKPD, Students’ worksheet, Desmos, Linear Function

\begin{abstract}
Abstrak
Salah satu usaha untuk memfasilitasi siswa dalam pembelajaran daring dan pembelajaran tatap muka terbatas saat pandemi adalah, digunakannya lembar kerja siswa digital untuk melatih kognitif siswa, khususnya pada matematika. Penelitian ini mempunyai tujuan yaitu untuk mengembangkan lembar kerja siswa elektronik berbasis masalah persamaan garis lurus menggunakan Desmos, untuk mengurangi dampak kemunduran belajar pada motivasi dan pemahaman siswa, dan juga untuk mengetahui hasil analisis kelayakan dari lembar kerja siswa elektronik yang sudah dibuat. Desmos adalah aplikasi berbasis web, yang khusus digunakan untuk pembelajaran matematika. Desmos menyediakan fitur kalkulator grafik dan aktivitas kelas untuk membantu siswa belajar dan menyukai matematika. Penelitian ini menggunakan model ADDIE dengan uji coba terbatas menggunakan enam siswa SMPN 3 Surabaya sebagai subjek. Analisis kelayakan dari lembar kerja siswa mendapat skor validitas 3,71 dengan kriteria sangat valid. Skor kepraktisan 3,74, dengan skor sangat praktis. Dan efektif karena, seluruh subjek mendapatkan skor Tes Hasil Belajar lebih tinggi, daripada nilai ketuntasan minimum SMPN 3 Surabaya. Hal penting yang perlu dicatat adalah, penelitian ini membutuhkan uji coba yang lebih besar dengan subjek yang lebih banyak untuk menilai aspek afektif lebih jauh dan secara komprehensif. Lembar kerja siswa elektronik ini dapat menjadi alternatif media untuk siswa SMP untuk berlatih materi persamaan garis lurus.
\end{abstract}

Kata kunci: E-LKPD, Lembar Kerja Siswa, Desmos, Persamaan Garis Lurus

Copyright (c) 2022 Dyah Ayu Karindra, Rooselyna Ekawati

$\triangle$ Corresponding author: Dyah Ayu Karindra

Email Address: dyahayukarindra@gmail.com (Jl. Ketintang, Gayungan, Surabaya, Jawa Timur, 60231)

Received 28 November 2021, Accepted 22 January 2022, Published 25 January 2022

\section{INTRODUCTION}

When the covid-19 pandemic happens in Indonesia, all aspects of life seem slow and postponed, including the education aspect. Instatusquo right now, schools should combine online learning and face-to-face learning to support continuity of learning during pandemic. Mustofa (2019) in (Husna et al., 2021) says that online learning is a virtual learning method using an internet network. Because of this change, teachers and students should adapt well. All learning media, including 
learning material, students' homework, worksheets, evaluation, should be in digital form and virtually sent. Thus, information and communication technology are crucial to support the continuity of learning in the pandemic.

But in reality, both teachers and students face many problems in online learning. Technically, because of bad networks in some remote areas and the expensive internet fee that some people can't afford. As a solution for that, The Indonesia Ministry of Education facilitates the internet learning quota for students and teachers (Diandra, 2020) and decided to hold restricted face-to-face learning since covid-19 case in Indonesia is decreasing, with the presence maximum of students is $50 \%$ and it held once per two weeks, Restricted face-to-face learning should be combined with online learning so that students can alternate learning with others. It means online learning still take a big part in students' learning. Some problems that students face in online learning are: (1) Some students don't have initiative to do self-learning, they tend to wait for instructions from teachers or parents, (2) Some students are not getting used to do online learning, (3) Students' target in learning is to get a high score, without considering its' process and their capability to understand the material. (4) Some students are not wise enough to regulate and control theirselves in self-learning, (5) Some students lack their comprehension of the material, so if they face problem, they can easily give up. Because of these reasons, teachers also can't see the students' progress and their way of thinking (Yulia \& Putra, 2020). Handayani (2020) in (Husna et al., 2021) also says that, one-sided interaction is also a problem in online learning. Students feel demotivated because of the limited interaction between each student and teachers. Thus, these factors could lead to learning loss, a condition of generation who lost their chance of learning, because of the learning process delay (Mahsun et al., 2021). Once learning loss happen, it could be hard to be back on track, since each topic in mathematics are essentials and connected.

Aware of the learning loss risks in mathematics, it is necessary to use math learning application that is easy to use, attractive, arouse students' interest in learning, and facilitate teachers and students in two-way interaction, even in online learning or restricted face-to-face learning. As an effort for that, this research wants to use Desmos inside mathematics learning and create an electronic students' worksheet (E-LKPD) using Desmos. Electronic students' worksheet is one of a digital learning media that can be used to practice students' cognitive. Contents inside of worksheet based on (Anggita et al., 2019) is summary, students' work instruction, learning goals, and exercise/activity that students will do. This electronic worksheet can be used in both online learning and face-to-face learning. This worksheet is designed so that students can find and understand the concept of slope in linear function through the activites inside of it, independently. Meanwhile, Desmos is a web-based application that specially created to be used in mathematics learning. Desmos combines features of graphic calculator and classroom activities to achieve its' goal, which is to help students study math and make them love math (Kristanto, 2019). Desmos can be accessed for free using internet network. Desmos can only work well using laptop or computers. Inside Desmos Activity Builder, all features can facilitate 
Development of Electronic Students' Worksheet Linear Function-Problem Based Using Desmos Application, Dyah Ayu Karindra, Rooselyna Ekawati

teachers to create attractive students' activity. Teachers can insert animation, figures, functions, tables, or video into it. Teachers can also create multiple choices in worksheet or create jumbled cards using multiple choice \& cardsort features. Research from Taufik \& Pagiling (2021) also support with the idea of Desmos can facilitate many kinds of students' activity such as designing a test, games or quizzes, and students' assignment to evaluate students' comprehension. Jon ORR (2017) in (Safarini \& Herman, 2020) says that Desmos Activity Builder can create good activities that gives chance for students to learn concept of mathematics, productively and comprehensively. Teachers can also see the progress of students in real time using Teacher Dashboard feature inside Desmos.

Background of this research are, the fact that not all mathematics learning in Indonesia support students to use a graphic calculator, even in online or face-to-face learning. And, also, Desmos was a new thing for mathematics learning in SMPN 3 Surabaya, and researchs using Desmos are still limited, rather than Geogebra as a graphic calculator. Taking into consideration the excellence and capability of Desmos, this research is aiming to create electronic students' worksheet using Desmos with the topic of slope in linear function for junior high school. The problem inside of worksheet will be in problem-based, with intention that it will become a meaningful learning, even if it's online. Students are expected to integrate their knowledge and skills to relevant context and expected to arouse a self-learn attitude \& critical thinking.

Previous researchs using Desmos, such as Safarini \& Herman (2020) and Ishartono et al (2018), were focused on the development skill of mathematics teacher using Desmos. Such that, writer wants to conduct new research that focus on students, which to create electronic worksheet using Desmos, based on valid, practical, and effective aspect. Research from Mumpuni (2018) and Puhl (2019) had same intention with writer's idea which to create media using Desmos, and test it in a class based on valid, practical, and effective aspect, but none of these research develop electronic worksheet. Due to this reason, writer wants to conduct this research.

The research questions for this study are: (1) How to develop linear function-problem based electronic worksheet using Desmos? (2) How is the eligibility analysis result of this electronic worksheet linear function-problem based using Desmos?

\section{METHOD}

This research was a Research and Development type, using ADDIE research model. Sugiyono (2013) said that research and development method goals are to create a product and test its' eligibility. ADDIE research model have five phases: Analysis, Design, Development, Implementation, and Evaluation (Putra, 2020). This research was conducted in SMPN 3 Surabaya with small group experiment. Based on Sahrul et al (2020), small group experiment can be done using 6 students representative, with low, middle, and high achievement. Then, six students representative from class $8 \mathrm{H}$ were chosen as subjects. These subjects are categorized into three groups consist of two, with achievement category mentioned above. The data of each student were based on teacher's report. 
The final product of this research is electronic students' worksheet inside Desmos Application. Activities inside this electronic worksheet are: (1) Summary, (2) Students' Worksheet, (3) Study Result Test, with every instruction in each activity. After activities inside of worksheet has already designed, the next step was to test its' eligibility through 3 aspects: valid, practical, and effective (Plomp \& Nieveen, 2007). For the validity aspect, the worksheet was given to one lecturer as a validator. Validation aspect in here, was tested using validation paper. Validation paper is consist of structured and unstructured questionnaire (Sahrul et al., 2020). The structured questionnaire was used to gain evaluation score of the worksheet from scale 1 to 4 . The unstructured questionnaire was used for validator to give her/his critics towards the worksheet as a basis for revision. There are two kinds of validation paper, validation paper of worksheet, and validation paper of Study Result Test. For the practical aspect, it was evaluated by the evaluation instrument score from Class $8 \mathrm{H}$ 's mathematics teacher and the students' response questionnaire. The practical paper is also consist of structured and unstructured questionnaire. Evaluation criteria of this worksheet was refers to (Mulyatiningsih, 2012) with score of $\mathrm{N}$ was gained from average score that given from validator, teacher, and students' response. And for the last aspect is effective, which means all subjects were expected to achieve same or higher score in Study Result Test than criteria minimum score of SMPN 3 Surabaya, which is 80.

Table 1. Evaluation Criteria of Worksheet Based on Mulyatiningsih (2012)

\begin{tabular}{|l|l|l|}
\hline Score $(\mathbf{N})$ & Criteria of Validity & Criteria of Practicality \\
\hline $3,25<\mathrm{N} \leq 4,00$ & Very Valid & Very Practical \\
\hline $2,50<\mathrm{N} \leq 3,25$ & Valid & Practical \\
\hline $1,75<\mathrm{N} \leq 2,50$ & Invalid & Not Practical \\
\hline $1,00 \leq \mathrm{N} \leq 1,75$ & Very Invalid & Not Very Practical \\
\hline
\end{tabular}

Revision also conducted, until the product can be concluded as valid, practical, and effective. This research was done using the flowchart of methodology as follows:

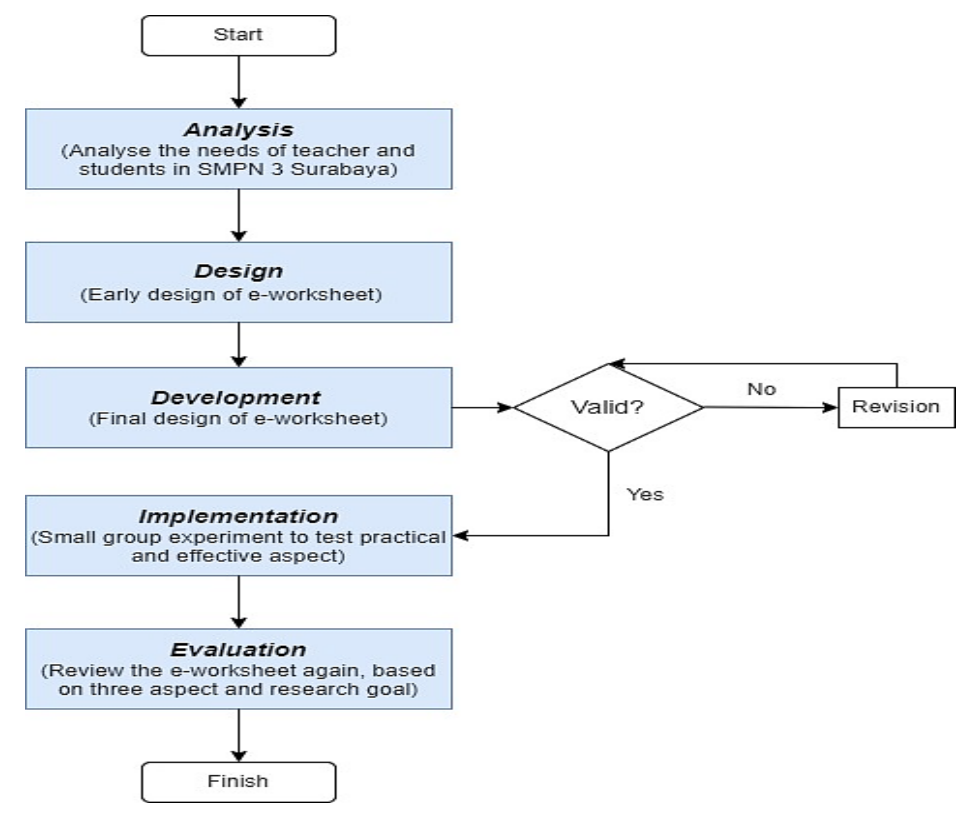

Picture 1. Research Methodology Flowchart 


\section{RESULT AND DISCUSSION}

\section{Analysis}

First phase was Analysis. Analysis in this research is divided into 2, problem analysis and material analysis. Observation and interview were conducted to see directly, how the restricted faceto-face learning and online learning were implemented in school. Writer also did consultation with math teacher towards the learning topic that will be used in the worksheet. As the result of material analysis, topic that used in this worksheet was linear function with standard competences (KD) \& indicators (IPK) that refers to Permendikbud No 22 Tahun 2016 of junior high school, as follows:

Table 2. Standard Competences (KD) \& Indicators (IPK) that Used in The Worksheet

\begin{tabular}{|l|ll|}
\hline Standard Competencies (KD) & \multicolumn{1}{|c|}{ Indicators (IPK) } \\
\hline $\begin{array}{l}\text { 3.4) Analyze linear function (as } \\
\text { linear equation) and interpreting its' } \\
\text { graph, which relate to contextual } \\
\text { problem. }\end{array}$ & 3.4 .1 & $\begin{array}{l}\text { Explain the standard form of } \\
\text { linear equation. } \\
\text { Create graph from linear } \\
\text { equation. } \\
\text { Determine the slope of the linear } \\
\text { equation. }\end{array}$ \\
$\begin{array}{l}\text { Determine the slope from two } \\
\text { known points. } \\
\text { Determine the equation of the } \\
\text { known graph. }\end{array}$ \\
$\begin{array}{l}\text { 4.4) Solve contextual problem which } \\
\text { relate to linear equation. }\end{array}$ & 3.4 .1 & $\begin{array}{l}\text { Solve contextual problem which } \\
\text { relate to linear equation. }\end{array}$ \\
\hline
\end{tabular}

Based on the observation and interview for the problem analysis, writer gains information that, math teacher of SMPN 3 Surabaya faces some problems inside learning. One of them is the school regulation during pandemic that oblige the form of math evaluation test to change into multiple choice. Thus, it makes teacher difficult to see and evaluate students' comprehension and way of thinking. Also, teacher was questioning on how to arouse students' motivation during online learning and restricted face-to-face learning. Another problem inside learning is mathematics online learning in SMPN 3 Surabaya is conducted with synchronous learning using Microsoft Teams. With this way of learning, teacher feels that students are not active enough to participate. And from the interview, a graphic calculator application was never used during online learning. However, the research of Montijo (2017) says, graphic calculator inside math learning can help students to take conclusion from a problem and improve their ability to solve problem.

On the other hand, students' characteristics in Class 8H SMPN 3 Surabaya are: (1) They have a good enough ability to operate smartphones or laptop, (2) Some of them may experience significant learning loss during pandemic. Learning loss based on The Education and Development Forum (2020) in (Pratiwi, 2021) is a phenomena which students experience academic setback, due to the 
delay of learning process. In the field, one student from the low achievement group was difficult to even understand one variable linear equation and integers, which were the prerequisite material of determining slope in linear function. Fortunately, the restricted face-to-face learning can be a solution to cope with learning loss, though gradually. It means that, teachers need to maximized quality of restricted face-to-face learning, in order to support students doing online learning at home. Taking into consideration of the problems and the excellence of Desmos, writer think that Desmos could be one of solutions to arouse students' motivation in math learning and also to create attractive classroom activity or e-worksheet that can use graphic calculator inside of it.

\section{Design}

Three main activities inside this electronic worksheet are: (1) Summary, (2) Students' Worksheet, (3) Study Result Test. First step in this phase was designing Students' Worksheet. This worksheet was inspired by an activity inside of Desmos named Land the Plane. After that, some problems inside of it were modified and adjusted in terms of language and difficulty level. Problems inside of worksheet were created into problem-based alike, with the context of a plane landing path. Problems inside of it were adjusted with IPK that already been made and were created in the form of essay test, in order to see students' way of thinking and students' accuracy (Masriyah, 2018). Writer also used some features of Desmos such as, graph, table, multiple choice, checkboxes, and sketch. Emoji also used to create attractive look of the worksheet. Direct feedback was also created to support the worksheet. Feedback in here such as, compliment if students' answer was right, and warning if students' answer was false. Feedback in this electronic worksheet can be used as media for teacher to communicate better with students, even in online learning. Herman (2005) inside (Febriyanti, 2015) says, the direct feedback inside worksheet can motivate students to try again until his/her answer was right. Instruction and the feedback in form of students' false notes, warning, and compliments, can be used to increase students' motivation and ability. To create this direct feedback, it needs a basic coding ability. Some examples of coding can be accessed inside Desmos Computation Layer feature. Students' worksheet here was consist of: opening slide, students' instructions, exercise/activity, and reflection. The design of students' worksheet was as follows:
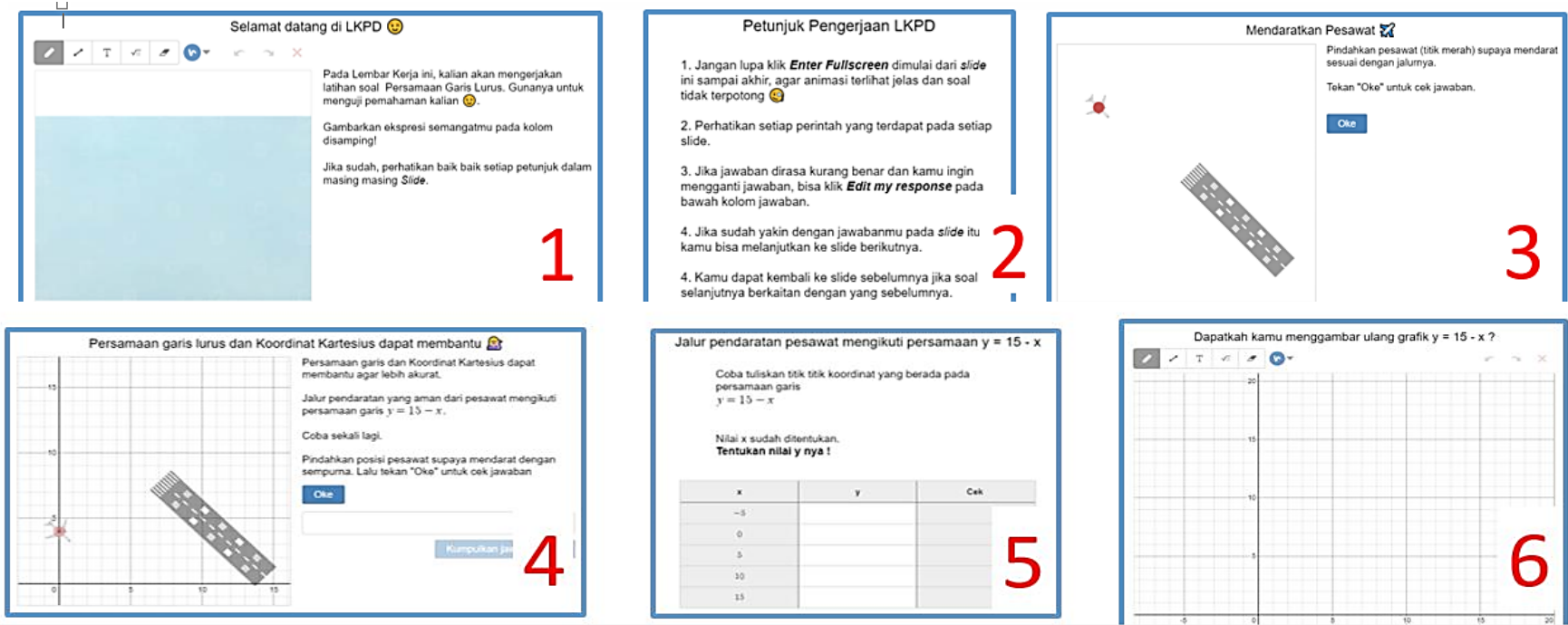
Development of Electronic Students' Worksheet Linear Function-Problem Based Using Desmos Application, Dyah Ayu Karindra, Rooselyna Ekawati

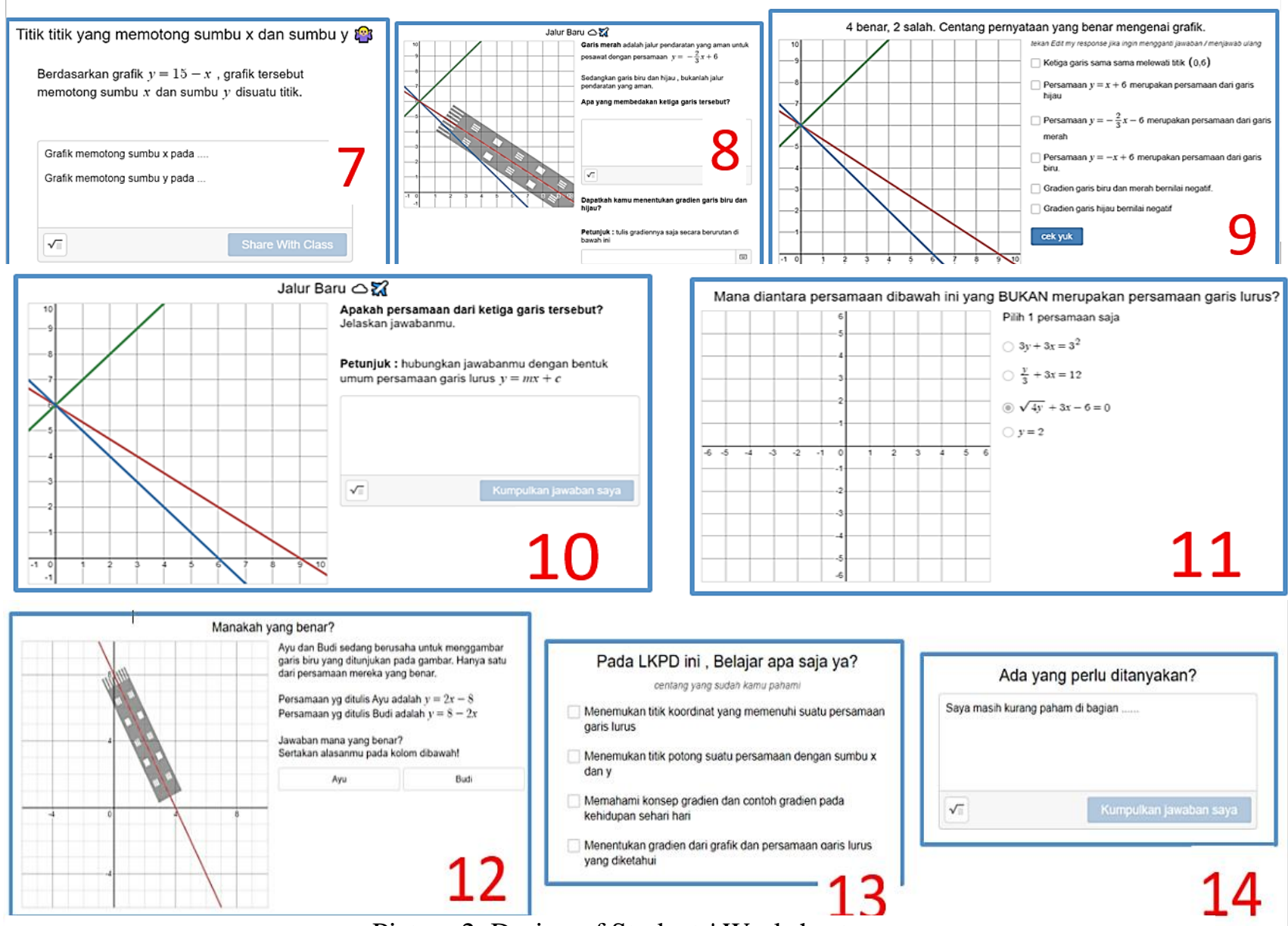

Picture 2. Design of Students' Worksheet

The second step in this phase was designing Summary. Summary was consist of opening slide, students' instructions, learning goals, and video explanation of linear function. The video explanation was created and recorded using Powerpoint and Bandicam. Then, it was inserted into Desmos Activity Builder. The design of summary activity was as follows:
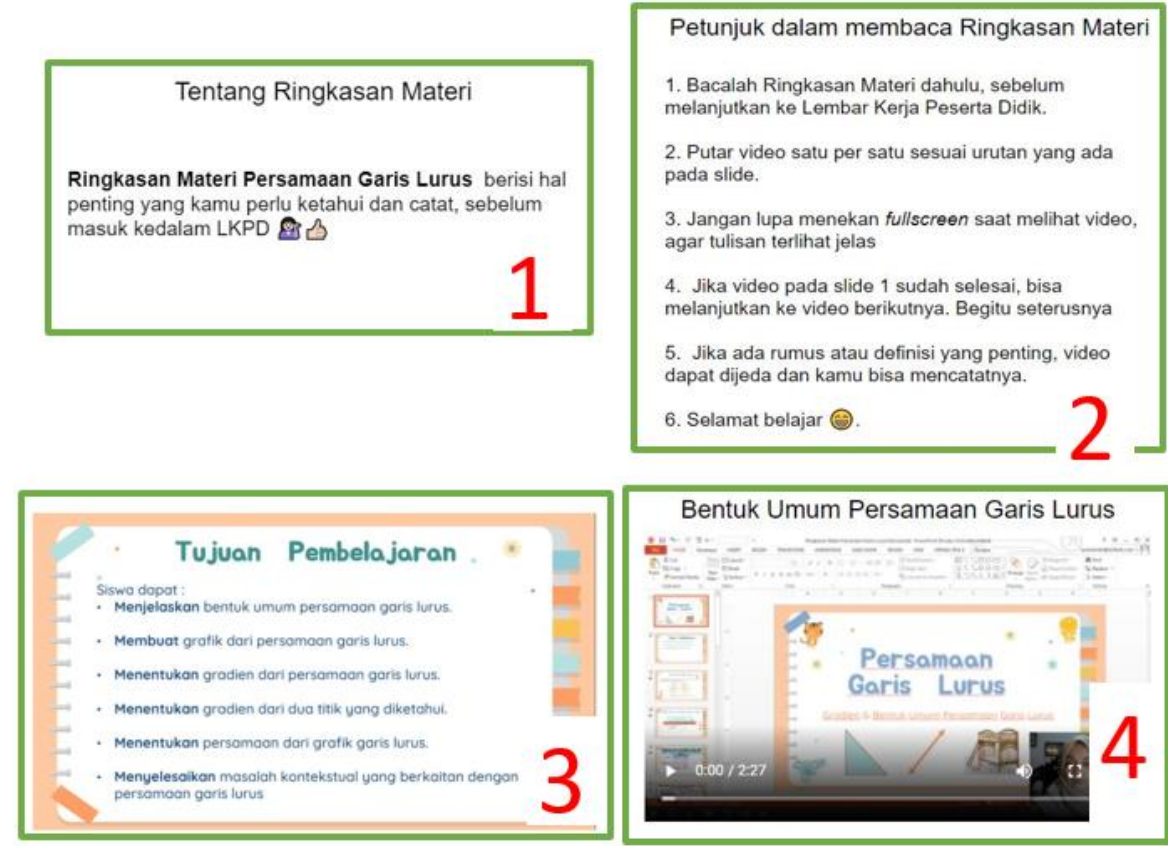

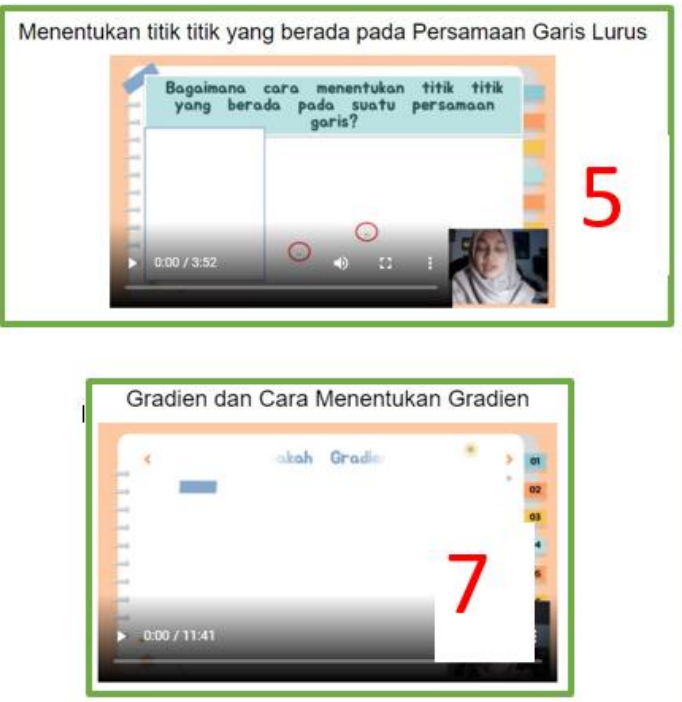
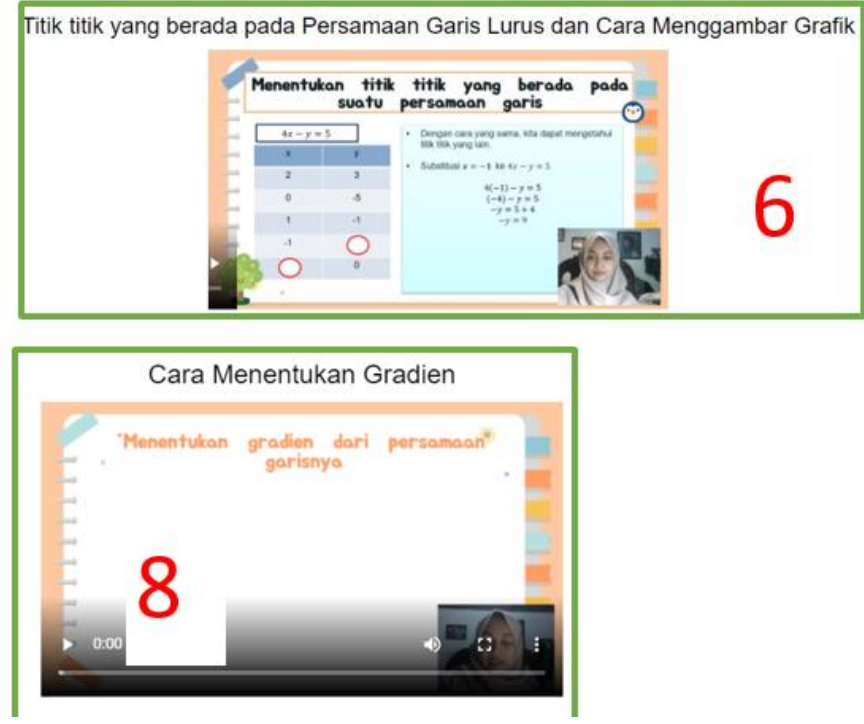

Picture 3. Design of Summary activity

The third step was designing Study Result Test activity. The problems inside of it were created based on indicators (IPK) that has been made. Problems were created in the form of objective test with definite answer. Thus, scoring can be done objectively (Masriyah, 2018). Problems in Study Result Test were created using multiple choice, cardsort, and marbleslides features. Study Result Test was consist of opening slide, students' instruction for the test, and reflection.
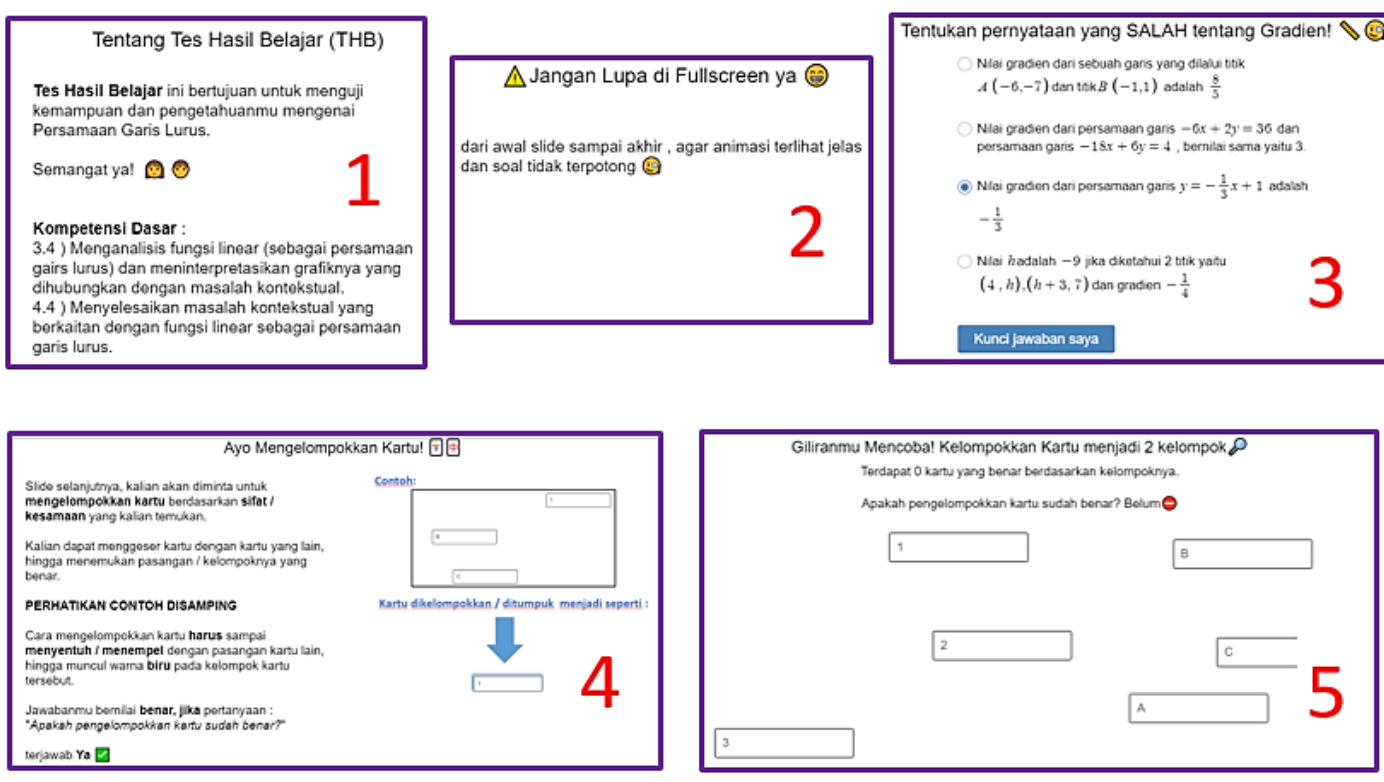
Development of Electronic Students' Worksheet Linear Function-Problem Based Using Desmos Application, Dyah Ayu Karindra, Rooselyna Ekawati
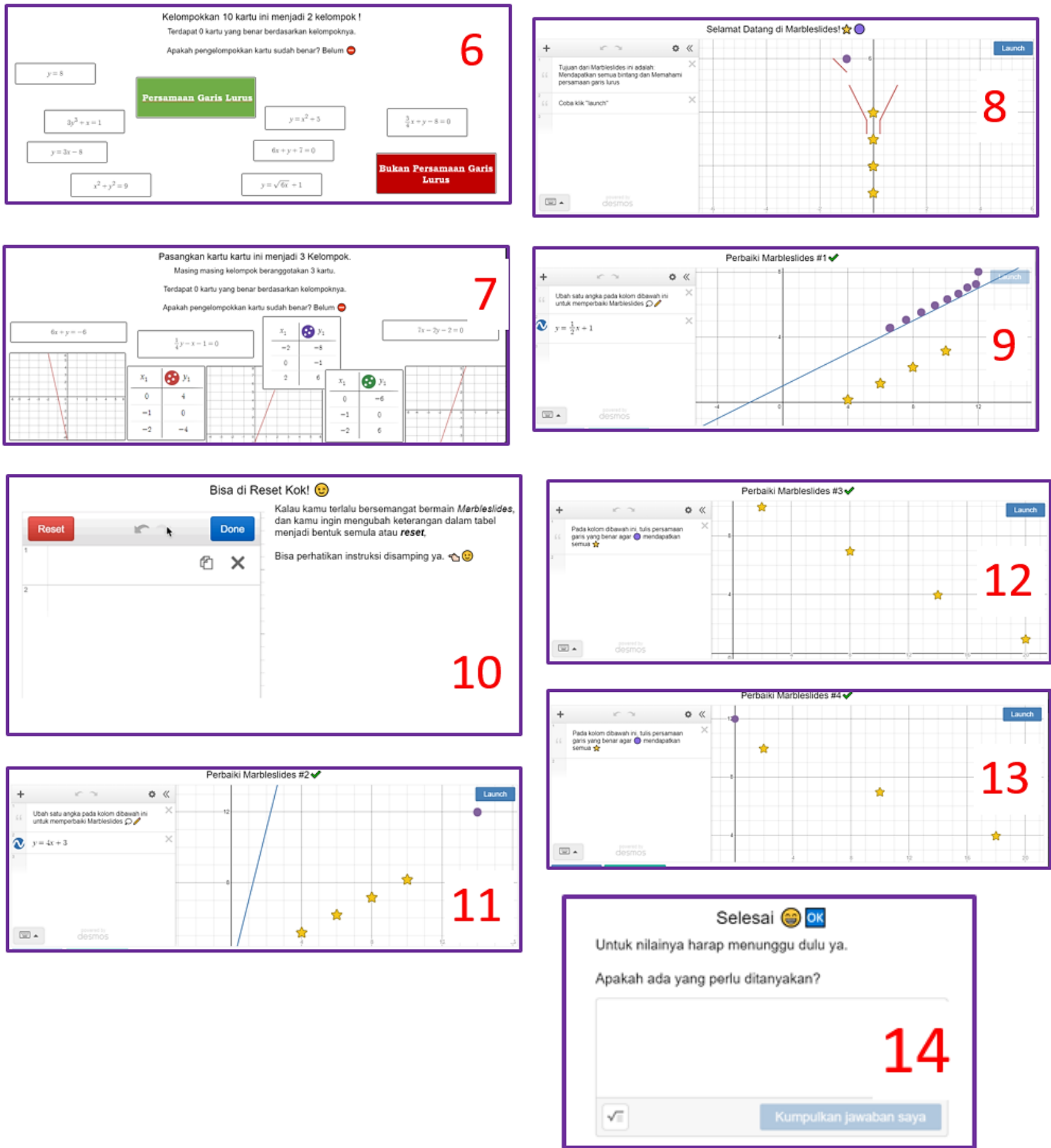

Picture 4. Design of Study Result Test activity

\section{Development}

Validation was done in this phase. The entire activities inside worksheet were validated to test whether they were valid or not. Output from this phase was the final design of electronic students' worksheet that valid and ready to be tested. One lecturer from Mathematics Education UNESA was doing the validation. There were 2 activities that validated: (1) Students' Worksheet, and (2) Study Result Test activity. The students' worksheet was evaluated by format, content, language, and 
appearance aspects. And for the study result test, it was evaluated by content, construction, and language aspects. (Putra, 2020). The result of validation was as follows:

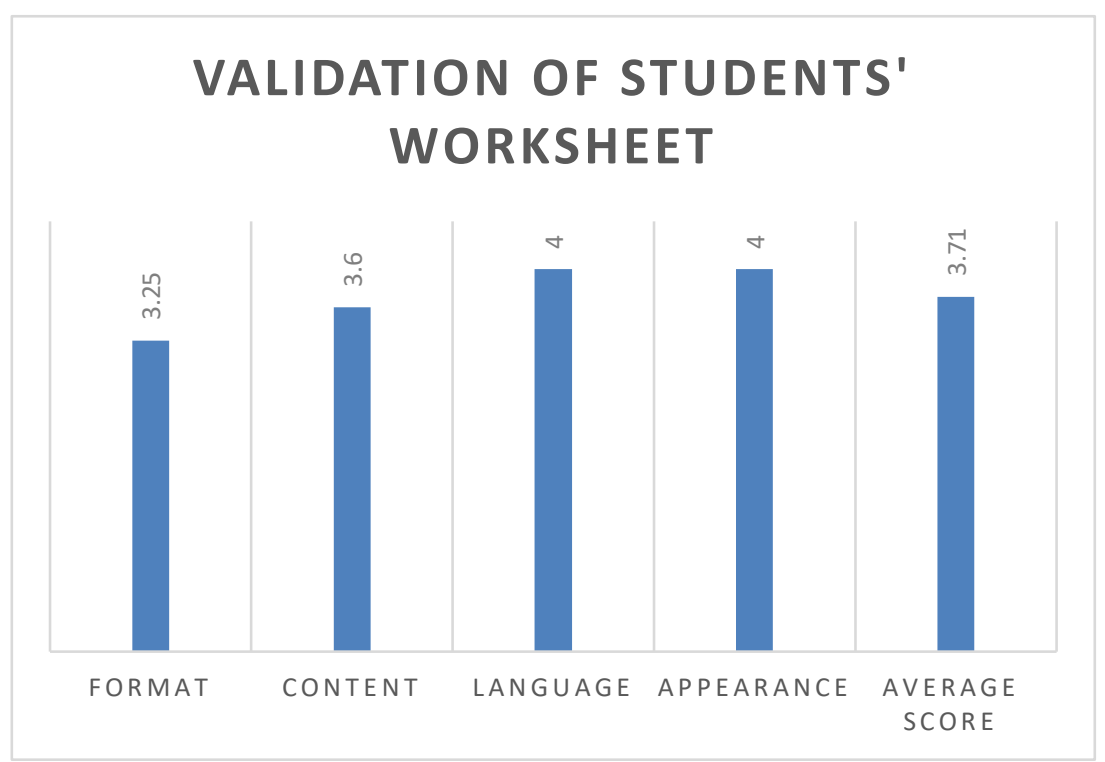

Picture 5. Validation of Students' Worksheet Activity

From Picture 5, the students' worksheet activity gained score 3.25 for format aspect, 3.6 for content aspect, 4 for language, and 4 for appearance. Such that, the average score was 3.71. From the evaluation criteria of worksheet, it achieved "very valid" criteria.

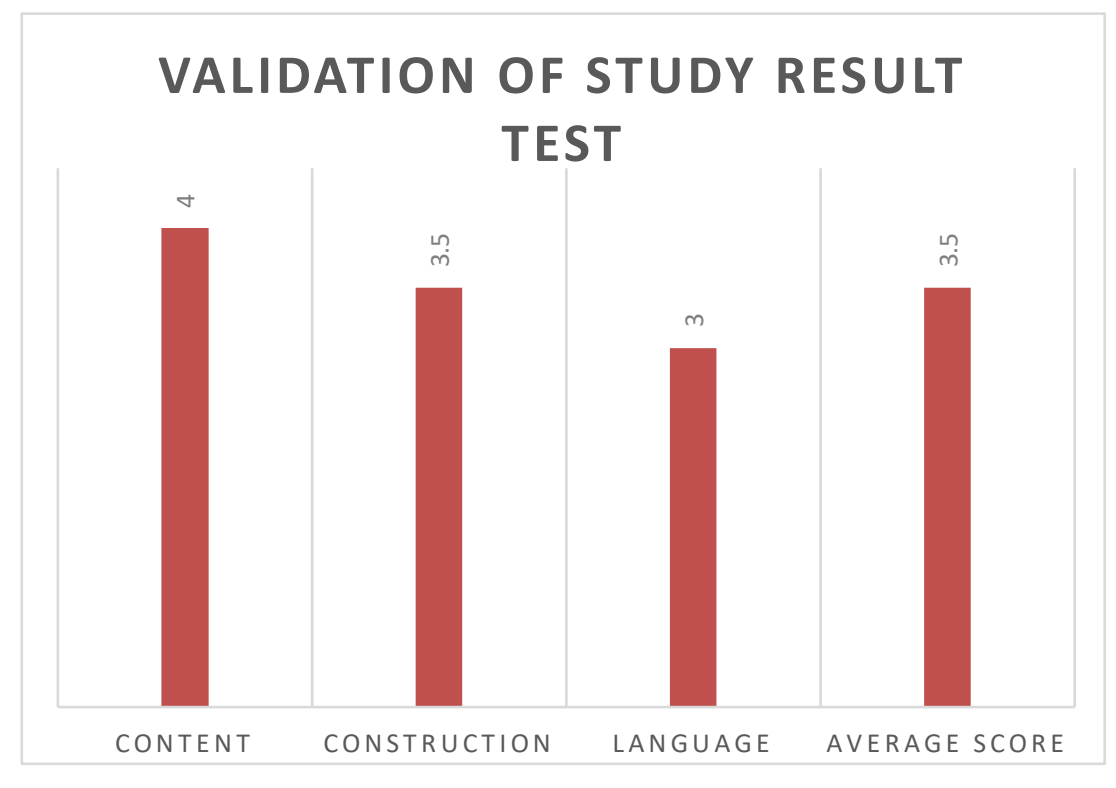

Picture 6. Validation of Study Result Test Activity

From Picture 6, the study result test activity gained score 4 for content aspect, 3.5 for construction aspect, and 3 for language. Thus, the average score was 3.5, and based from the evaluation criteria of worksheet, it achieved "very valid" criteria. It's important to note, validator also gave some critics towards the entire activities, most of them were in terms of language in the students' 
Development of Electronic Students' Worksheet Linear Function-Problem Based Using Desmos Application, Dyah Ayu Karindra, Rooselyna Ekawati

instructions, problems, and inside the video explanation. So, revision was also conducted until it satisfy validator's suggestions. The final design of electronic students' worksheet using Desmos can be accessed through: https://student.desmos.com/?prepopulateCode=6a5uyr .

\section{Implementation}

After the entire activities inside e-worksheet has been valid, then the small group experiment was conducted. Based on Sahrul et al (2020), small group experiment can be done using 6 students representative. Then, the experiment was done using six students of Class 8H SMPN 3 Surabaya, as subjects. These subjects are categorized into three groups consist of two,with the category of high, middle, and low achievement group. This small group experiment was chosen, due to the condition of restricted face-to-face learning. Information related to subjects were gained from teacher's data. Some problems during implementation phase were adjusting students' schedule. Some of them only did two activities: Summary and Students' Worksheet in school, and then for Study Result Test was done at home. This condition proves that the electronic worksheet can be implemented in face-to-face or online learning.

This small group experiment's goals was to evaluate practical and effective aspects of the electronic worksheet. Subjects were expected to do total three activities inside the electronic worksheet, then students' response questionnaire was given to them. This questionnaire was given to see, subject response and enthusiasm towards the e-worksheet. After that, subjects were given Study Result Test to see how the result of their learning after use the e-worksheet. Their score of Study Result Test was expected to achieve the same or higher score than criteria minimum score of SMPN 3 Surabaya. To evaluate practical aspect, here writer used teacher's evaluation instrument, and students' response questionnaire. And for the effective aspect, it was evaluated from students' score in Study Result Test.

In this phase, we gained information that, all six subjects gained higher score than 80 in Study Result Test. Two subjects from low achievement group were gained 85. Two students from middle achievement group were gained 100. And two students from high achievement group were gained 100. Based on Rohma (2014), if students' score is the same or higher than criteria minimum score in their school, it means that students were successfully achieve learning goals. By that, it can be conlcluded that, the e-worksheet has already fulfil the effective aspect.

From the result of teacher's evaluation instrument, it gained 3.77 average score with "suitable" criteria. This score was based on teacher's observation during the small group experiment using the eworksheet. Meanwhile, for the result of students' response questionnaire was gained average score of 3.71 from six students (subjects). Criteria that gained from the teacher's instrument and students' response were "very practical", refers to the evaluation criteria of worksheet by (Mulyatiningsih, 2012).

From the students' questionnaire, majority of subjects said that they didn't feel burdened using the e-worksheet. They felt that this worksheet was a new thing for them, so they were happy to get 
new learning experience. Subjects also felt motivated after the e-worksheet using Desmos was implemented. The instruction inside of it were easy to be followed by them. And from the teacher's perspective, this e- worksheet was attractive enough, and it may decrease students' learning loss in comprehension and motivation aspects. This e-worksheet also equipped with video explanation, exercise/worksheet, study result test, and reflection. This e-worksheet was very practical to be implemented in both online and face-to-face learning. Teacher hoped, this kind of worksheet will be available for other math topics.

\section{CONCLUSION}

The development of this electronic students' worksheet linear function-problem based, was using Desmos. Desmos was a special application for mathematics learning, a web-based, with graphic calculator and classroom activity features inside of it. Research goals of this study were: (1) To develop students' worksheet linear function-problem based using Desmos, (2) To know the eligibility analysis result of the worksheet. The result of the first goal was the entire activities inside e-worksheet using Desmos website, in link https://student.desmos.com/?prepopulateCode=6a5uyr . For the result of the second goal was, the e-worksheet that fulfil criteria of valid, practical, and effective. After some revision, this e-worksheet can be used as alternative media for middle-school students to practice Slope in Linear Function. The excellence of this e-worksheet are: (1) Suitable for online and face-toface learning, because it's web-based, (2) Teacher can see students' way of thinking when they're doing worksheet, (3) Students can use a graphic calculator inside math learning, and develop their skills. (4) It has attractive look and various forms of questions. The drawback of this worksheet are the needs of a good internet network, and it only work well to access it using laptop/PC.

After doing the entire phase of research, writer expect the upcoming research will: 1) Test the worksheet with bigger group of experiment, to evaluate effective aspect further and comprehensively. 2) Modify and adjust this e-worksheet as you expect it to be, in the topic of determining slope of linear function or another math topics.

\section{REFERENCES}

Anggita, Y. V., Muslim, A., \& Irianto, S. (2019). Pengembangan Lembar Kegiatan Peserta Didik (Lkpd) Matematika Materi Pengukuran Sudut Berbasis Model Discovery Learning Pada Kelas Iv Sekolah Dasar. Jurnal Elementaria Edukasia, 2(2), 121-125.

Diandra, E. (2020). Ini Perbedaan Kuota Umum Dan Kuota Belajar Di Bantuan Kuota Kemendikbud.

Kompas. Https://Edukasi.Kompas.Com/Read/2020/09/23/195500071/Ini-Perbedaan-KuotaUmum-Dan-Kuota-Belajar-Di-Bantuan-Kuota-Kemendikbud

Febriyanti, C. (2015). Pengaruh Bentuk Umpan Balik Dan Gaya Kognitif. 3(3), 203-214.

Husna, R., Roza, Y., \& Maimunah. (2021). Identifikasi Kesulitan Guru Matematika Dalam Pelaksanaan Pembelajaran Daring Di Masa Pandemi Covid-19. Jurnal Kependidikan: Jurnal 
Development of Electronic Students' Worksheet Linear Function-Problem Based Using Desmos Application, Dyah Ayu Karindra, Rooselyna Ekawati

Hasil Penelitian Dan Kajian Kepustakaan Di Bidang Pendidikan, Pengajaran Dan Pembelajaran, 7(2), 9.

Ishartono, N., Kristanto, Y. D., \& Setyawan, F. (2018). Upaya Peningkatan Kemampuan Guru Matematika Sma Dalam Memvisualisasikan Materi Ajar Dengan Menggunakan Website Desmos The 8 Th University Research Colloquium 2018 Universitas Muhammadiyah Purwokerto. 7886.

Kristanto, Y. D. (2019). Creating Interactive And Mathematically Rich Activity With Desmos. Online Resource, 1-34.

Mahsun, M., Ibad, T. N., \& Nurissurur, A. (2021). Model Belajar Synchronous Dan Ansynchronous Dalam Menghadapi Learning Loss. 04(01), 123-139.

Masriyah. (2018). Asesmen Proses Dan Hasil Belajar. Unesa.

Montijo, E. (2017). The Effects Of Desmos And Ti-83 Plus Graphing Calculators On The ProblemSolving Confidence Of Middle And High School Mathematics Students. Liberty University.

Mulyatiningsih. (2012). Riset Terapan. Uny Press.

Mumpuni, P. W. (2018). Pengembangan Media Pembelajaran Online Berbantuan Web Desmos Untuk Materi Grafik Fungsi Kuadrat Pada Sma Kelas X.

Plomp, T., \& Nieveen, N. (2007). An Introduction To Educational Design Research.

Pratiwi, W. D. (2021). Dinamika Learning Loss: Guru Dan Orang Tua. Jurnal Edukasi Nonformal, 2(1), 147-153.

Puhl, L. (2019). The Effect Of Using Desmos In High School Algebra When Teaching The Slope Of A Line (Vol. 1, Issue 1). Http://Www.Ghbook.Ir/Index.Php?Name= فرهن و رسانه هاى نوين\&Option=Com_Dbook\&Task=Readonline\&Book_Id=13650\&Page=73\&Chkhashk=Ed9c94 91b4\&Itemid=218\&Lang=Fa\&Tmpl=Component\%0ahttp://Www.Albayan.Ae\%0ahttps://Schol ar.Google.Co.Id/Scholar?Hl=En\&Q=Aplikasi+Pengena

Putra, Z. (2020). Pengembangan Lembar Kerja Peserta Didik Bangun Ruang Sisi Lengkung Berbasis Augmented Reality.

Rohma, D. (2014). Pengembangan Perangkat Pembelajaran Materi Geometri Dengan Hands On Activity Di Smp Negeri 1 Gresik.

Safarini, D., \& Herman, T. (2020). An Analysis Of Pre-Service Mathematics Teachers' Desmos Activities For Linear Programming Lesson. International Journal Of Pedagogical Development And Lifelong Learning, 1(1), Ep2002. Https://Doi.Org/10.30935/Ijpdll/8312

Sahrul, S., Yuanita, P., \& Maimunah, M. (2020). Pengembangan Perangkat Pembelajaran Matematika Berbasis Model Discovery Learning Untuk Memfasilitasi Kemampuan Komunikasi Matematis Peserta Didik Smp Kelas Viii. Jurnal Cendekia : Jurnal Pendidikan Matematika, 4(2), 626-636. Https://Doi.Org/10.31004/Cendekia.V4i2.277

Sugiyono. (2013). Metode Penelitian Kuantitatif, Kualitatif, Dan R\&D (19th Ed.). Alfabeta.

Taufik, A. R., \& Pagiling, S. L. (2021). Matappa: Jurnal Pengabdian Kepada Masyarakat 
Penggunaan Desmos Dalam Memvisualisasikan Pembelajaran Matematika Bagi Guru Mgmp Matematika Kabupaten Merauke. 4, 122-128.

Yulia, I. B., \& Putra, A. (2020). Kesulitan Siswa Dalam Pembelajaran Matematika Secara Daring. Refleksi Pembelajaran Inovatif, Vol. 2, No. 2, 2020, 2(2), 327-335. 